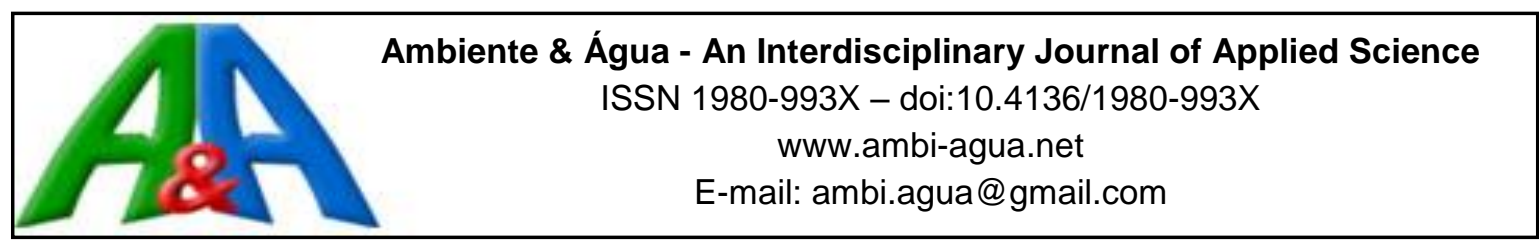

\title{
Production of energy (biodiesel) and recovery of materials (biochar) from pyrolysis of urban waste sludge
}

\author{
ARTICLES doi:10.4136/ambi-agua.2128
}

Received: 27 Apr. 2017; Accepted: 05 Jan. 2018

\author{
Arianna Callegari' ${ }^{\text {; }}$ Petr Hlavinek ${ }^{2}$; Andrea Giuseppe Capodaglio ${ }^{*}$ \\ ${ }^{1}$ Università degli Studi di Pavia, Pavia, Italy \\ E-mail: arianna.callegari@unipv.it, andrea.capodaglio@unipv.it \\ ${ }^{2}$ Brno University of Technology, Brno, Czech Republic \\ E-mail: hlavinek.p@fce.vutbr.cz \\ "Corresponding author
}

\begin{abstract}
Safe disposal of sewage sludge is one of the most pressing issues in the wastewater treatment cycle: at the European Union level, sludge production is expected to reach $13 \mathrm{Mt}$ by year 2020. Sludge disposal costs may constitute up to, and sometimes above, $50 \%$ of the total cost of operation of a WWTP, and contribute to over $40 \%$ of its GHGs emissions. The most common disposal options at the moment are landfilling, disposal in agriculture (about $40 \% \mathrm{EU}$ wide), incineration or co-incineration, and use in the industrial production of bricks, asphalts and concrete. Sewage sludge, however, still contains beneficial resources such as nutrients, that can be recovered through specific processes (e.g. precipitation as struvite) and energy, recoverable through a variety of approaches. Microwave-assisted pyrolysis of urban waste sludge was applied for the production of oil, (Syn)gas, and biochar that were afterwards characterized and compared to mainstream alternative fuels (biodiesels) and other material recovery options. Sustainability issues related to the production of biodiesel/biochars from urban wastewater treatment sludge are also discussed. The paper shows that waste urban sludge can indeed be a full component of the urban circular economy by allowing, if properly processed, recovery of energy resources at multiple levels: bio-oils (biodiesel), syngas and biochar, all having definite advantages for final residues use and disposal. Biodiesel, in particular, allowing energy recovery as liquid fuel, offers a much more flexible and efficient utilization.
\end{abstract}

Keywords: biochar, biodiesel, materials, microwaves, pyrolysis, sustainable energy, urban waste sludge.

\section{Produção de energia (biodiesel) e recuperação de materiais (biochar) a partir da pirólise de resíduos de lodo urbano}

\section{RESUMO}

A eliminação segura das lamas de esgoto é uma das questões mais urgentes no ciclo de tratamento de águas residuais: a nível da União Européia, espera-se que a produção de lamas atinja 13 Mt até o ano 2020. Os custos de disposição das lamas podem constituir-se e às vezes acima de 50\% Custo total de operação de uma ETAR e contribui para mais de $40 \%$ das emissões de GEEs. As opções de eliminação mais comuns no momento são: aterro, eliminação na agricultura (cerca de $40 \%$ em toda a escala), incineração ou co-incineração, uso na produção 
industrial de tijolos, asfaltos, concreto. As lamas de esgoto, no entanto, ainda contêm recursos benéficos, como nutrientes, que podem ser recuperados através de processos específicos (por exemplo, precipitação como estruvita) e energia, recuperável através de uma variedade de abordagens. A pirólise assistida por microondas de lama de lixo urbano foi aplicada para a produção de petróleo, gás (Syn) e biochar que posteriormente foram caracterizados e comparados aos principais combustíveis alternativos (biodiesels) e outras opções de recuperação de materiais. São discutidos os problemas de sustentabilidade relacionados à produção de biodiesel / biochars de lamas de tratamento de águas residuais urbanas. $\mathrm{O}$ documento mostra que o lodo urbano residual pode de fato ser um componente completo da economia circular urbana, permitindo, se devidamente processado, a recuperação de recursos energéticos em vários níveis: bio-óleos (biodiesel), gás de síntese e bio-carbon, todos com vantagens definidas para o uso e eliminação de resíduos finais. O biodiesel, em particular, que permite a recuperação de energia como combustível líquido, oferece uma utilização muito mais flexível (e eficiente).

Palavras-chave: biochar, biodiesel, energia sustentável, lodo de resíduos urbanos, micro-ondas, pirólise.

\section{INTRODUCTION}

Residual urban sludge disposal costs may constitute up to, and sometimes above, $50 \%$ of the total cost of operation of Wastewater Treatment Plants (WWTPs) and contribute more than $40 \%$ of the total greenhouse gas (GHG) emissions associated with their operation (Liu et al., 2013). The safe disposal of such sludge is literally a "big" issue in urban wastewater treatment: at the European Union level, the 2020 sludge production is expected to reach close to $13 \mathrm{Mt}$ by year 2020, an increase of more than 30\% from today's levels. According to Machado (2001), urban waste sludge production in Brazil is much lower (about $150 \mathrm{Kt}$ per year) since about 80 million people in Brazil do not have their wastewater collected by centralized systems, but disposed of through separate unitary (septic tanks) systems, in which there is no centralized control over the final destination of excess organic solids. Part of the population have their wastewater collected by communal systems, but not yet treated. In practice, only less than 45 million Brazilians get their wastewater treated. Clearly, the size of the issue will inevitably increase as wastewater collection and treatment in Brazil increases, as has been seen elsewhere in the world. In 2008, the United Nations Human Settlement Programme more than doubled the previous estimate by Machado for the country, updating it to $370 \mathrm{kt}$ per year (Mateo-Sagasta et al., 2015).

Traditionally, wastewater sludges are processed for: a) reduction of total weight and volume to facilitate their transport and subsequent treatments; b) stabilization of contained organic material and destruction of pathogenic microorganisms, elimination of noxious odours, and reduction of putrefaction potential; and, for the last few decades, and at an increasing degree, c) value addition by developing economically viable recovery of energy and residual constituents, such as nutrients, that can be recovered through specific processes (e.g. precipitation as struvite), and energy, recoverable through a variety of approaches.

Wastewater still contains significant amounts of resources (i.e. nutrients) and energy; most of these end up, after treatment, immobilized in residual sludge. According to Shizas and Bagley (2004) the theoretical chemical energy content of wastewater is approximately $3 \mathrm{~kJ} / \mathrm{g}$ (dry w.), which is roughly 10 times the energy expenditure necessary to treat the same wastewater in a current-technology WWTP. As of today, conventional technology allows the recovery, through anaerobic sludge digestion, of just a small fraction of that estimated value, allowing WWTPs to cover at most $1 / 4$ to $1 / 2$ of their energy needs (Capodaglio et al., 2017). By 
sheer mass balance proportions, wastewater sludge can be shown to contain about 5 times the energy stored in wastewater. Table 1 illustrates some figures reported by different researchers.

Table 1. Energy content estimates (kJ/g dry w.) for different sludge types.

\begin{tabular}{cccc}
\hline Primary Sludge & Secondary Sludge & Digested Sludge & Source \\
\hline 15.9 & 12.4 & 12.7 & Shizas and Bagley (2004) \\
15 & 13.5 & 11.4 & Zanoni and Mueller (1982) \\
n.a. & n.a. & 12.6 & Vesilind and Ramsey (1996) \\
\hline
\end{tabular}

In Table 1, digested sludge refers to sludge processes through secondary (anaerobic) digestion after a first-stage liquid treatment. In Brazil and other South American countries, it is common practice nowadays to treat urban wastewaters through UASB processes (Capodaglio, 2017) as this process is much less energy-intensive, and could be almost as efficient as traditional aerobic processes used in EU and the USA, due to the local, favorable climatic conditions. UASB processes can, in theory, also allow energy recovery from wastewater; however, in the few full-scale applications visited by the authors, this was rarely implemented in practice. In any case, the residual energetic value of anaerobic sludge after a UASB process should be comparable to the values indicated in Table 1 for digested sludge.

The EU Landfill Directive 99/31/EC sets restrictions (quantitative targets) for biodegradable municipal wastes (such as sewage sludge) disposed of in landfills; in addition, the national legislation of some Member States have set very strict limits for organic matter or total organic carbon (TOC) contained in disposed-of sludge, prohibiting de facto its landfilling. According to recent Eurostat data, in fact, significant abandonment of sludge landfilling practices is occurring in most of Europe, except for Italy, Denmark, and Estonia. Sewage Sludge Directive 86/278/EEC, concerning beneficial use of sludge on soils, initially sought to encourage safe use of sewage sludge in agriculture, regulating this form of disposal to prevent harmful effects. After concerns raised about possible harmful accumulation of compounds in soils, 16 (out of 27) EU countries have set more stringent requirements for heavy metals in sludge, compared to the Directive's provisions, and 10 countries set stricter limit values for heavy metals in soil. Such restrictions are being strengthened periodically, while most EU countries have outright prohibited the disposal of untreated sludge in soil. Composting is applied more often in the new EU-12 countries, compared to the old EU-15.

Finally, incineration is enforced in most EU-15 countries. Greece, Slovenia, Germany and Netherlands present the greatest increasing trends, even though the first two countries export sludge for incineration; Denmark, Austria, Belgium and Italy show instead decreasing incineration trends (Kelessidis and Stasinakis, 2012).

Thermal processing of sludge remains, however, a convenient and efficient approach for the disposal of waste urban sludge without causing excess secondary pollution, which is used as much as possible in many countries. Thermal utilization of sludge comes into play when the sludge does not comply with, or is in excess of, requirements for disposal in agriculture, and allows forms of energetic recovery. Thermal processing of sludges can take several forms. Cofiring in power plants and heating plants with coal (approximately 5\% sludge) does not significantly decrease the temperature of the combustion process, and usually does not require extra investment costs for off-gas cleaning, as existing filters and separators can handle this extra component. Co-firing in cement kilns was considered the most convenient technology in terms of both sludge disposal and utilization: one ton of dried sludge can substitute up to 0.33 $\mathrm{t}$ of raw material and, since ash from sludge is bound to cement clinker, this can actually be considered a waste-less technology. This is also considered a "waste-to-energy" system, and is acceptable if no other environmentally friendly technology can be applied (Capodaglio et al., 
2016a). Incineration (with urban solid waste, or in special sludge incinerators) is another option, where the energy contained in the sludge contributes to the energy balance of the process.

Sewage sludge is usually processed, prior to disposal, in anaerobic tanks to produce biogas, a mixture of $\mathrm{CH}_{4}$ and $\mathrm{CO}_{2}$ that can be used as such, or further refined to obtain bio-methane, a renewable fuel with characteristics practically identical to those of fossil methane (Capodaglio et al., 2016b).

However, recent work has demonstrated that the production of biodiesel using lipids extracted from sewage sludge could be economically feasible because of the remarkably high yield of oil and low cost of this feedstock.

Recent work has demonstrated that production of biodiesel from lipids contained in sewage sludge, largely regardless of its upstream production processes (i.e. WWTP technology), could be an alternative, economically feasible technique for energy recovery from waste biological sludges, , as compared to conventional biodiesel feedstocks (Bharathiraja et al, 2014), thanks to high oil yields, as shown in several studies (Olkiewicz et al., 2012; Capodaglio et al., 2016c).

Furthermore, while conventional biodiesel feedstocks is usually expensive and competing with other uses (e.g. food for animals, or people), waste sludge is abundant, costly to dispose of under traditional schemes, and therefore should be available almost everywhere at very low, or no cost, as a feedstock.

Brazil has a standing tradition of biodiesel uses, derived from both food and non-food crops, and from various food-waste products (e.g. spent frying oils). This type of solution is widely supported by the Brazilian government within its Biodiesel Production and Use Program (BPUP), which favours renewable energies, specifically addressing energy self-sustainability of isolated rural communities (Torres et al., 2013). No references were found, however, concerning the recovery of biodiesel and materials from urban waste sludge in Brazil. This is probably due to the fact that the sludge disposal problem has not reached critical proportions as it did in several in several EU member states.

Several technologies have been studied for this purpose worldwide. While transesterification is perhaps the most-used biodiesel-extraction process in Brazil, pyrolysis could be a technology to consider, not only in urban waste sludge processing, but also in other energy/materials recovery chains, as it allows useful recovery of energy and materials at different levels. These include pyrolysis, hydrothermal liquefaction, wet oxidation, supercritical water oxidation, sequential methane/hexanol distillation (Demirbas, 2001). These, once process-validated and industrially tested, could be considered not only as viable alternative processes for sludge disposal, but also sustainable, environmental-compliant biodiesel production processes. In addition to biodiesel, waste urban sludge may provide, as by-products, other substrates of notable energetic and material values, such as biochar.

Studies show that for oil extracted from waste sludge, the energy gain is up to $29.7 \mathrm{GJ} / \mathrm{ton}$ (Zhang et al., 2013). Furthermore, GHG emissions studies show that biodiesel production from sludge is a net carbon dioxide capture process, with the highest capture being around $40 \mathrm{t} \mathrm{CO}_{2} / \mathrm{t}$ biodiesel produced. Sludge-derived biodiesel, finally, has a lower Global Warming Potential (GWP) than most other renewable biodiesels (Table 2) with the exception of biodiesel derived from waste vegetable oils (Dufour and Iribarren, 2012).

Table 2. Comparison of GWP ( $\mathrm{kg} \mathrm{CO}_{2}$ equivalent) of different biofuels.

\begin{tabular}{cccccccc}
\hline $\begin{array}{c}\text { Biodiesel } \\
\text { type }\end{array}$ & $\begin{array}{c}\text { Waste } \\
\text { vegetable } \\
\text { oil }\end{array}$ & $\begin{array}{c}\text { Beef } \\
\text { tallow }\end{array}$ & $\begin{array}{c}\text { Poultry } \\
\text { fat }\end{array}$ & $\begin{array}{c}\text { Sewage } \\
\text { sludge }\end{array}$ & Soybean & Rapeseed & $\begin{array}{c}\text { Low- } \\
\text { sulphur } \\
\text { Fossil } \\
\text { Diesel }\end{array}$ \\
\hline $\begin{array}{c}\mathrm{GWP} \\
(\mathrm{kg} \mathrm{CO} \text {-eq) }\end{array}$ & 16.97 & 23.32 & 23.55 & 20.84 & 26.18 & 63.23 & $\mathbf{8 3 . 6 9}$ \\
\hline
\end{tabular}


This paper illustrates experimental findings from the application of pyrolysis treatment to urban waste sludge, and describes possible recovery pathways of energy and materials from that feedstock. In addition to the benefits in potentially contributing to solve the significant problem of the ultimate disposal of urban waste sludge, this technology could be instrumental in supporting current government commitments (e.g. EU's under Directive 2003/30/EC, on the promotion of biofuels for transport) to achieve in the next coming years higher fractional targets of bio-oils' content in commercial fuels (e.g. 10\% by 2020 in the EU) (Raboni et al., 2015).

\section{MATERIALS AND METHODS}

Pyrolysis is a thermal-decomposition process, carried out in the absence of $\mathrm{O}_{2}$, that converts biomass into solid charcoal (biochar), bio-oil (biodiesel, or SSPO, Sewage Sludge Pyrolysis Oil), and gaseous products (syngas) at elevated temperatures (generally more than $500^{\circ} \mathrm{C}$ ) and atmospheric pressure. It is one of the most efficient processes for biomass conversion discovered and industrially adopted to date. Recovered SSPOs are a complex mixture of aliphatic, aromatic and poly-aromatic hydrocarbons, long carbon-chain organic acids and alcohols, etc. (Pokorna et al., 2009), very similar in properties to diesel fuel (hence the alternative term, "biodiesel").

Pyrolysis not only can be used to transform biomass of various origins and other waste materials (e.g. rubber tyres) into bio-oil, biochar, and syngas, of varied characteristics (depending on initial feedstock and actual process operating conditions), but also allows for variation in the ratios between different product fractions, according to process temperature profiles and duration. In a sense, pyrolysis allows the user to choose among the three possible final products, according the best-fitting combination required by local reuse/recycle needs (Capodaglio et al., 2016c).

While the advantage of obtaining sludge-derived liquid fuels is easily obvious to most, more so than gaseous fuel, which is subject to greater transportation and use challenges than the former, the solid fraction residue from the process (biochar) also has been found to have several useful, unexpected applications. Biochar is a new technical term indicating "the porous carbonaceous solid produced by the thermochemical conversion of organic materials in an oxygen depleted atmosphere that has physicochemical properties suitable for safe and longterm storage of carbon in the environment" (Shackley et al., 2012). Biochar could in theory be used to generate energy (it has an energy content that, depending on the process used for its production, can be even $>18 \mathrm{MJ} / \mathrm{kg}$ ); however, biochar is recently getting much attention from the scientific community due to its various use potentials. Given its properties, it is clear that the concept of biochar production from sewage sludge has become increasingly popular in recent years.

Microwave technology has recently emerged as one of the most promising methods of enhancing and accelerating chemical reactions, due to efficient heat-transfer profiles. It is therefore being adopted as one of the best technologies available in pyrolytic processes, since it reduces residence time and brings significant energy savings (Motasemi and Azfal, 2013). Microwave-assisted pyrolysis (MAP) technology is an alternative heating method already in use in biomass pyrolysis for biofuels production, presenting several advantages over conventional pyrolysis, including: uniform internal heating for material particles, since electromagnetic energy is directly converted into heat at a molecular level; ease of control due to its instantaneous response; simple set-up, facilitating its adaptation to large-scale industrial processes; reduced need for feedstock grinding; and low cost, as microwave is a mature and energy-efficient technology. The different heating mechanisms make MAP products retain different characteristics from those obtained with conventional heating. In addition, MAP takes a much shorter process time than conventional pyrolysis (Menendez et al., 2002; Leszczynski, 2006), as the heating of the feedstock biomass is more uniform. 
Using monomodal microwave synthesizers (MMS) instead of multimodal ones, the need for preliminary mixing dry sludge with microwaves receptors additives reported by earlier researchers could also be eliminated, and the process temperature needed for process completion is significantly lowered (as low as $270^{\circ} \mathrm{C}$ ), allowing the production of a larger liquid product (biodiesel) fraction (Capodaglio et al., 2016c). Detailed description of pyrolysis, MAP and MMS-driven pyrolysis are given by Masek et al. (2013).

The apparatus shown in Figure 1 was used to expose sludge samples to MAP. The experimental apparatus consists of a pure quartz cuvette (Fig. 1[a]), capable of withstanding high temperatures exceeding $1000^{\circ} \mathrm{C}$, with a cavity (Fig. 1 [b]) containing the sludge sample (15-25 g) being treated. A MMS, unlike a conventional (multimodal) cooking microwave oven, is capable of matching the impedance between the load to be irradiated and the microwavegenerator (magnetron), thus maximizing the power transfer to the samples. With an MMS appropriately tuned, it is also possible to irradiate dry samples, eliminating the need reported by previous researchers to add microwave receptors to the sludge, a task impossible to achieve with traditional microwave ovens that heat contents indirectly, by agitation of the water molecules contained in the samples. A triple-stub matching device (MD, Alter Systems, Fig. 1[e]) connected with the magnetron was used to balance reflective coefficients within the system, allowing the creation of an optimal electric field intensity in the cavity containing the sample.

Sludge samples were prepared from dewatered waste sludge obtained from the local municipal WWTP that had already undergone an anaerobic digestion process. Samples were further desiccated at $60^{\circ} \mathrm{C}$ for 24 hours in order to further reduce their water content to around $73.5 \%$, while minimizing any possible reaction that could modify their organic content. This desiccation phase will be the object of additional considerations about the sustainability of the process at the full-scale. The desiccated sample was then ground to a fine powder, and pyrolyzed in this apparatus.

Determination of oil content was made after condensation of process evaporate with a Soxhlet extractor after each test (See Tests 1-7 in Table 3), and its chemical characterization was then performed by GC-MS spectrometry. Test conditions varied according to maximum temperature achieved in the cuvette, time of sample exposure to maximum temperature, timeto maximum temperature (heating rate of sample). Biochar characterization was achieved after grinding and sieving to $<0.5 \mathrm{~mm}$ the resulting product. Determination of volatile matter and ash content was conducted according to ASTM-D1752-84, elemental composition (C, H, N) assessed by an elemental analyser (Thermo Fisher Scientific, MA. USA), O content by Vario El Cube (Elementar Analysensysteme, GmbH).

Table 3 shows temperature, duration and quantity of extracted oils from the tests conducted. The greatest oil yields were observed between 270 and $500^{\circ} \mathrm{C}$. Below $200^{\circ} \mathrm{C}$, the oil quantity obtained is very small; over $500^{\circ} \mathrm{C}$, there is still some production.

\section{RESULTS AND DISCUSSION}

The highest oil yield was obtained at the test temperature of $280^{\circ} \mathrm{C}(25.0 \%$ oil to organics sludge fraction, $12.52 \%$ oil to total sludge, weight basis) and short process duration. Higher temperatures and longer process times tend to increase the amounts of generated gaseous and solid fractions.

GC-MS analysis of extracted oil samples, diluted with dichloromethane, show the following composition (Figure 2). Toluene and styrene do not show in some of the graph lines due to the high dilution ratio adopted for analysis; however, they were detected in the raw oil samples. From lower to higher retention times (left to right in the graphs) MS identifies aromatic 
hydrocarbons (containing one or more aromatic rings in their molecular structure), nitrogenous compounds, alkanes, carboxylic acids (containing the $-\mathrm{COOH}$ or the $-\mathrm{OH}$ groups linked to a carbonyl group $\mathrm{C}=\mathrm{O}$ ), sterols and derivatives.

The lower calorific value (LCV) of the biodiesel obtained, is slightly lower than the one obtained from energy crops. Sludge-derived biodiesel LCV was about $33 \mathrm{~kJ} / \mathrm{g}$ (in the range $33-35 \mathrm{~kJ} / \mathrm{g}$ for all tests), against that from corn and safflower at $42-43 \mathrm{~kJ} / \mathrm{g}$, or the one from coconut feedstock at $38 \mathrm{~kJ} / \mathrm{g}$ commonly reported (Capodaglio et al., 2016c). Compared with fossil diesel, therefore, this sludge-derived oil has an LCV that is about $30 \%$ lower. LCV will vary according to process conditions: at higher process temperatures, the LCV of obtained biooil will tend to be lower for the same feedstock.

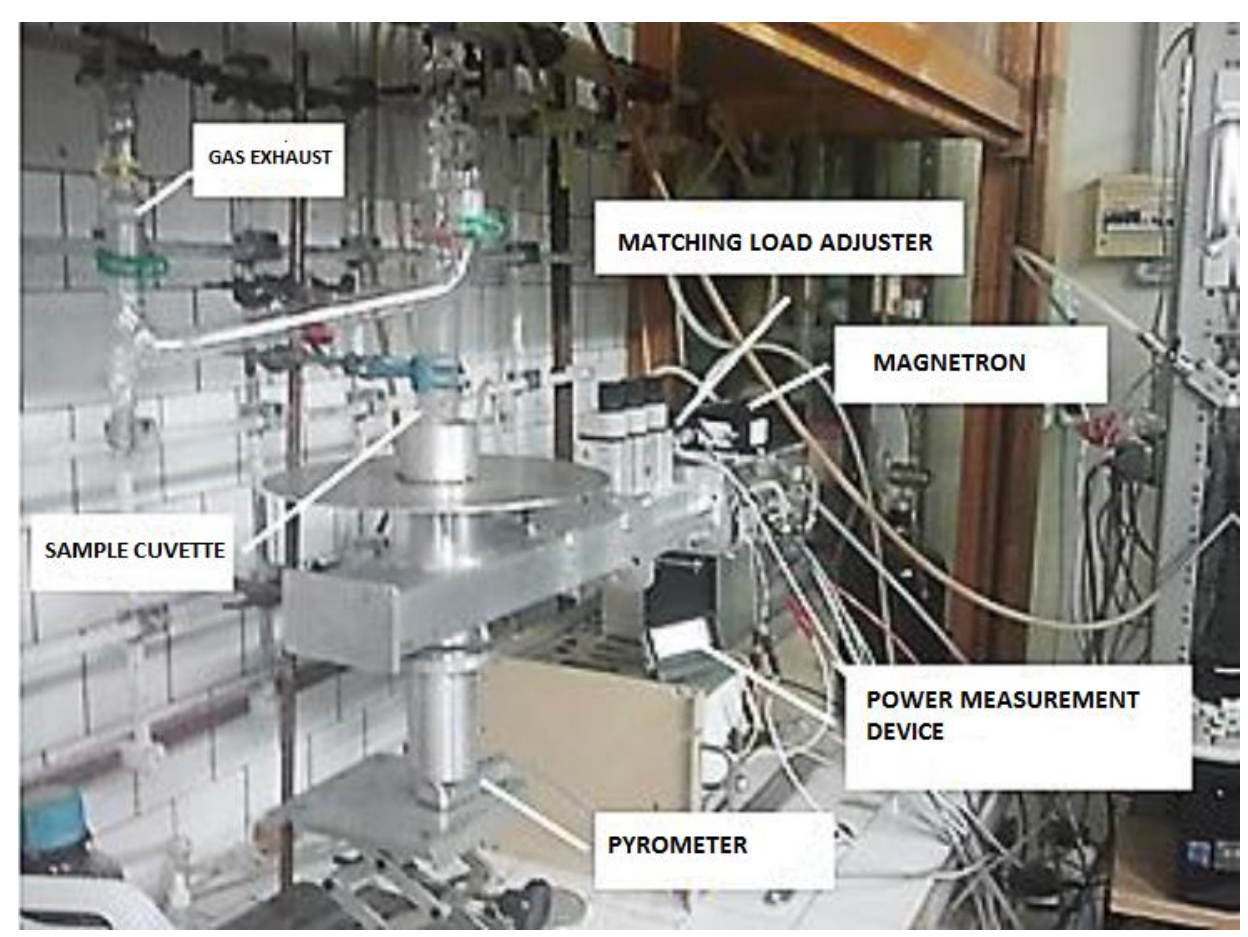

Figure 1. The experimental MMS apparatus.

Table 3. Tests conditions and oil yields.

\begin{tabular}{cccccc}
\hline & $\begin{array}{c}\text { Max Test } \\
\text { Temp. }{ }^{\circ} \mathrm{C}\end{array}$ & $\begin{array}{c}\text { Time at } \\
\mathrm{T}_{\mathrm{MAX}} \\
{[\mathrm{min}]}\end{array}$ & $\begin{array}{c}\text { Total } \\
\text { process } \\
\text { Time [min] }\end{array}$ & $\begin{array}{c}\text { \% oil to } \\
\text { total } \\
\text { sludge }\end{array}$ & $\begin{array}{c}\text { \% oil to } \\
\text { sludge } \\
\text { org. fraction }\end{array}$ \\
\hline SLUDGE AS IS & 60 & $=$ & $=$ & $3.57^{*}$ & $7 *$ \\
TEST 1 & 180 & 28 & 50 & 3.30 & 7 \\
TEST 2 & 270 & 20 & 55 & 9.68 & 19 \\
TEST 3 & 280 & 2 & 8 & 12.52 & 25 \\
TEST 4 & 400 & 2 & 18 & 10.77 & 22 \\
TEST 5 & 490 & 1 & 54 & 10.25 & 21 \\
TEST 6 & 600 & 3 & 56 & 8.71 & 17 \\
TEST 7 & 650 & - & 60 & 7.38 & 15 \\
\hline
\end{tabular}

*extraction with solvent from original sample. 


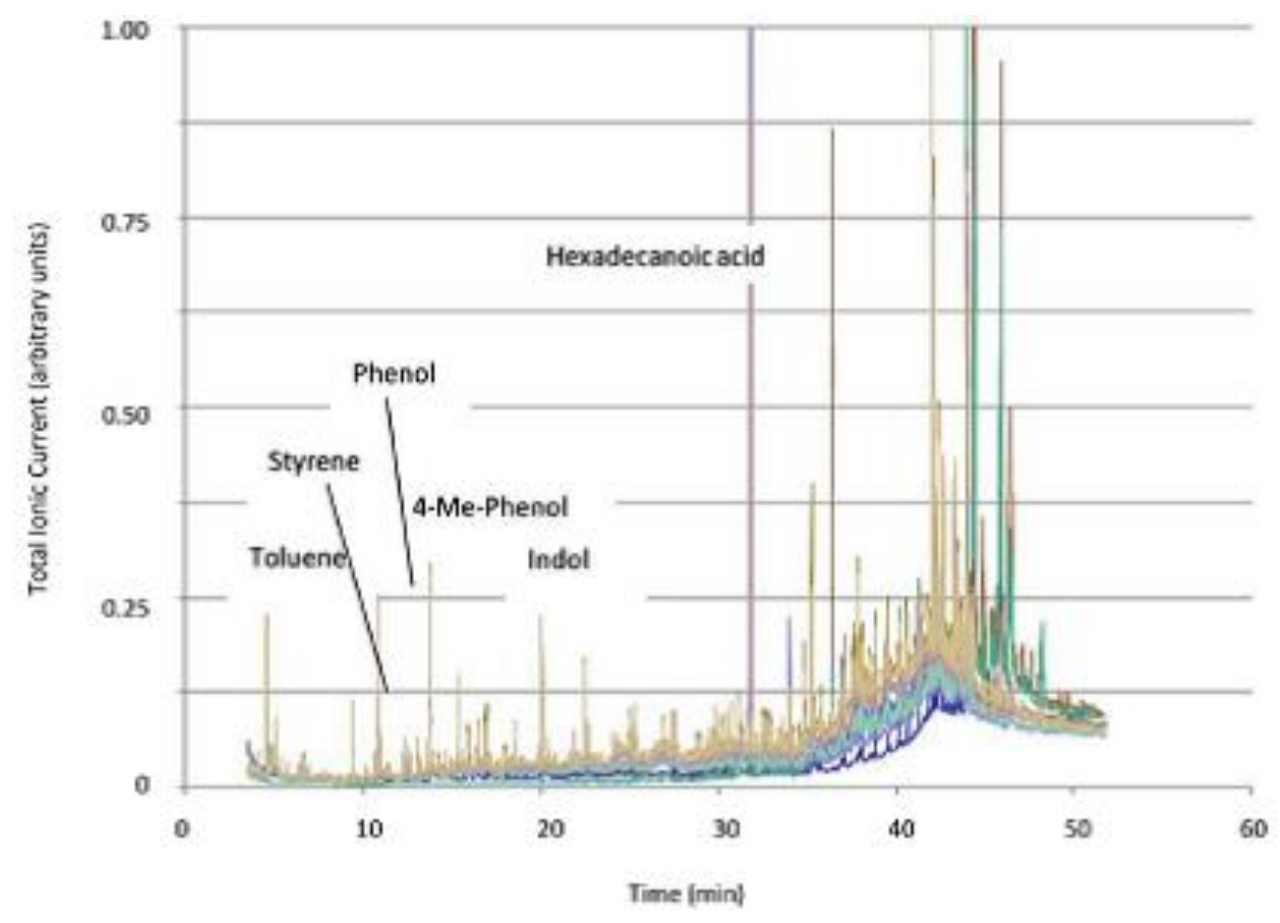

Figure 2. Superimposed GC-MS analytical results for the oil extracted in the different tests (From Capodaglio et al., 2016c).

Syngas is primarily composed of $\mathrm{H}_{2}$ and $\mathrm{CO}$, with smaller quantities of $\mathrm{CH}_{4}, \mathrm{CO}_{2}, \mathrm{H}_{2} \mathrm{O}$, and other low molecular-weight volatile organics. While its heating value is low ( $6 \mathrm{MJ} \mathrm{kg-1)}$ compared to natural gas ( $54 \mathrm{MJ} \mathrm{kg}-1)$, it can provide fuel for hot water, sludge pre-drying or electricity onsite. Given the low LCV and its "dirty" composition, it is usually not considered worthy of further processing (unless purposefully generated in high quantities). Some time ago, before widespread availability of natural gas, syngas was generated to provide energy for home heating, cooking, street lighting, etc. (a.k.a. "town gas"). At the moment, although providing some residual energetic value, syngas is the least interesting product of waste sludge pyrolysis.

Biochar is the solid residue of the process, with high energy content, that can be therefore burned in systems fed with pulverized coal. $\mathrm{NO}_{\mathrm{x}}$ emissions from biochar combustion are comparable to those of coal, requiring similar abatement technologies. Some types of feedstock (i.e. urban sludge) may contain relatively high levels of metals that concentrate in the biochar after pyrolysis. Biochars, however, may also have many other attractive, high value uses, in fields such as chemistry, metallurgy, agriculture, waste treatment, etc. Table 4 shows characteristics of biochar derived from sewage sludges with traditional and microwave-assisted pyrolysis, by the authors and in other studies. As it can be seen, the characteristics of the material vary according to the process adopted and depending on the origin of the feedstock material. Table 5 shows some of the main ash components of sewage sludge biochar from different origins. Process operational temperature has a substantial effect on the quality of biochar produced: biochar produced at low temperatures is most suitable for agricultural uses, due to carbon content and nutrient availability, while higher temperatures can improve its porosity and thus enhance its effectiveness in adsorbing contaminants present in soils (Agrafioti et al., 2013). Researchers have also shown that the pyrolysis process can suppress heavy metal release by non-impregnated biochars, resulting in an extremely low environmental risk using sludge-derived biochar as soil amendment (unlike the case of sludge as is). Biochars can be obtained under different processes and feedstocks; they significantly differ from one to another in their properties, depending on the type of biomass used to produce them, its growth conditions and also on pyrolysis operating conditions. 
It has already been recognized that oils derived from wastewater sludge are comparable replacements of traditional biodiesel production feedstock (Bharathiraja et al., 2014). In order to assess the sustainability of biodiesel production from this source, energy balance and greenhouse gas (GHG) emissions are also essential factors to consider.

It has been reported that biodiesel produced from two major food crop feedstocks, soybean and sunflower oils, has an energetically unfavorable energy balance, due to the low-oil yield of the crops, translating to a process energy loss of $32 \%$ for soybean, and $118 \%$ for sunflower (Pimentel and Patzek, 2005). Therefore, replacement of traditional feestock with better-suited raw or recovered materials is continuously being investigated. Wastewater sludge fulfils the basic general requirements of alternative feedstocks, that should be abundant, sustainable, and energetically favorable (i.e. generate a positive energy balance).

Sludge-derived biodiesel thus has a lower Global Warming Potential (GWP) than most other renewable biodiesels with the exception of biodiesel derived from waste vegetable oils (Dufour and Iribarren, 2012; Capodaglio and Callegari, 2017). Compared to conventional lowsulphur diesel as a benchmark, a $75.1 \%$ reduction for use of sludge-derived biodiesel can be achieved.

The transformation of waste sludge in biochar by pyrolysis has also some relevant environmental advantages. In the introductory section a brief review of the existing methods of excess sewage sludge disposal was presented. In addition to the saved costs for the otherwise necessary disposal of sewage sludge, this section shows the beneficial (added-values) uses by which biochar can become a resource.

The most appealing feature of biochar is the fact that it is an inexpensive, sustainable and easily-produced material with potentially extensive applications. Even though most of those applications are still in their infancy, biochar already has a number of identified applications with potentially extraordinary effects, including soil amendment, catalysis, water purification, and many others still to be invented or discovered.

Beneficial effects of biochar on agricultural crops yield and properties of soil have been studied, showing significant improvement in the yield of crops (Chan et al., 2008). Biochar addition is known to improve nitrogen fertiliser-use efficiency by improving the chemical properties of soil. It significantly increases soil $\mathrm{C}$ content, and improves crop productivity. Wastewater sludge biochar application was specifically found to increase soil cation exchange capacity (CEC) by up to $40 \%$, and soil pH by up to one unit (Hossain et al., 2010), with improvement of plant available nutrients, and carbon sequestration.

Biochars are receptive to complex metal ions present in the soil on their surfaces and therefore reduce their bioavailability, resulting in a reduced risk. Studies detected insignificant bioaccumulation in crops of metals present in wastewater-sludge biochar. In addition, biochar is known to have positive effects on soil quality, as it enhances soil aeration, increasing water holding capacity and improved environmental conditions for the growth and development of plant root systems. 
Table 4. Characteristics of biochar derived from sewage sludges with traditional and microwave-assisted pyrolysis.

\begin{tabular}{|c|c|c|c|c|c|c|c|c|c|c|c|c|c|c|c|c|}
\hline Source & \multicolumn{4}{|c|}{ Zielinska et al. (2015) } & \multicolumn{3}{|c|}{ Lu et al. (2013) } & \multicolumn{3}{|c|}{ Agrafioti et al. (2013) } & \multicolumn{3}{|c|}{ Antunes et al. (2013) } & \multicolumn{3}{|c|}{ Authors (this paper) } \\
\hline Type of sludge & \multicolumn{4}{|c|}{ Municipal WWTPs (4) } & \multicolumn{3}{|c|}{ Municipal WWTPs (3) } & \multicolumn{3}{|c|}{ Municipal WWTP } & \multicolumn{3}{|c|}{ Municipal WWTP } & \multicolumn{3}{|c|}{ Municipal WWTP } \\
\hline Pyrolysis process & \multicolumn{4}{|c|}{ Traditional slow } & \multicolumn{3}{|c|}{ Traditional slow } & \multicolumn{3}{|c|}{ Traditional } & \multicolumn{3}{|c|}{ MAP } & \multicolumn{3}{|c|}{$\begin{array}{c}\text { Monomodal Microwave- } \\
\text { assisted }\end{array}$} \\
\hline Sample/Temp. ${ }^{\circ} \mathrm{C}$ & Original & 500 & 600 & 700 & Original & 300 & 600 & Original & 300 & 500 & Original & 300 & 800 & Original & 270 & 500 \\
\hline Yield (\% dry w.) & - & $45-54$ & $43-51$ & $40-49$ & - & n.d. & n.d. & - & $58.1-64$ & $27-31$ & - & 91 & 77 & - & - & - \\
\hline Ash content $(\%)$ & $55.8-61.3$ & $64-73$ & $63-77$ & $68-79$ & n.d. & n.d. & n.d. & 25.9 & n.d & n.d. & 55.5 & 55.8 & 63.3 & $52-55$ & $54-57$ & $58-61$ \\
\hline Carbon $(\mathrm{C}, \%)$ & $21.6-26.2$ & $18.9-26.6$ & $18.4-27.7$ & $18.1-27.8$ & $23.8-33.2$ & $21.7-31.5$ & $15.2-26$ & 37.9 & 39.7 & 9.8 & 19.9 & & & $22-25$ & $20-22$ & $17-21$ \\
\hline$(\mathrm{O}+\mathrm{N}) / \mathrm{C}$ & $0.32-0.66$ & $0.25-0.29$ & $0.15-0.28$ & $0.09-0.21$ & n.d. & n.d. & n.d. & n.d. & n.d. & n.d. & 1 & & & - & - & - \\
\hline $\begin{array}{c}S_{\text {micro }}\left(\mathrm{m}^{2} \mathrm{~g}^{-1}\right) \\
\text { (Micropore surf.) }\end{array}$ & - & 7.1-19.4 & $2.8-7.7$ & $1.4-27.7$ & - & $4-6.7$ & 6.3-18.2 & - & $0.5-18$ & $4-90$ & 16.64 & 50.06 & 64.67 & - & - & - \\
\hline $\mathrm{pH}$ & $7.01-7.39$ & $7.08-7.25$ & $80.5-11.4$ & $12.2-13.1$ & 6.08 & 6.2 & 9.6 & 5.9 & 6.0 & 11.6 & 6.13 & 6.42 & 6.6 & $7.2-7.45$ & $7.3-7.55$ & $7.5-7.88$ \\
\hline
\end{tabular}

Table 5. Main ash components for some reported biomass feedstocks.

\begin{tabular}{lccccccccccc}
\hline Source & \multicolumn{3}{c}{ Zielinska et al. (2015) } & \multicolumn{4}{c}{$\begin{array}{c}\text { Lu et al. (2013) } \\
\text { (note different data units) }\end{array}$} & \multicolumn{3}{c}{$\begin{array}{c}\text { Authors } \\
\text { (this paper) }\end{array}$} \\
\hline Sample/Temp ${ }^{\circ} \mathrm{C}$ & Original & 500 & 600 & 700 & Original & 300 & 600 & Original & 270 & 500 \\
Fe (\% d.w.) & $1.1-6.8$ & $2.4-11.5$ & $2.37-12.5$ & $2.6-13.2$ & $0.8-23.2^{*}$ & $18.6-37.6^{*}$ & $0.06-43.2^{*}$ & $2.2-4.9$ & $2.8-7.3$ & $3.68-9.4$ \\
Si (\% d.w.) & $2.5-5.8$ & $4.8-9.1$ & $5.1-9.4$ & $5.5-97$ & - & - & - & $2.8-5.3$ & $3.6-8.6$ & $4.6-10.2$ \\
P (\% d.w.) & $3.4-4.9$ & $5.4-9.6$ & $5.3-9.2$ & $5.6-9.5$ & $20-28.4^{*}$ & $29.5-42.6^{*}$ & $35.5-57.6^{*}$ & $3.6-4.5$ & $4.72-7.18$ & $5.2-9.82$ \\
S (\% d.w.) & $1.5-3.8$ & $1.37-4.6$ & $1.2-3.97$ & $1.37-5.2$ & $0.7-1.1$ & $0.5-0.67$ & $0.43-0.57$ & $1.65-4.02$ & $1.88-4.5$ & $1.85-4.3$ \\
Al (\% d.w.) & $1.8-2.5$ & $2.3-3.3$ & $2.6-3.7$ & $2.7-3.9$ & $26.2-31^{*}$ & $38.1-52^{*}$ & $50.8-55.2^{*}$ & $1.98-2.75$ & $2.17-2.94$ & $2.15-3.33$ \\
Mg (\% d.w.) & $0.57-2$ & $0.9-3.3$ & $1.08-2.6$ & $1.1-2.4$ & $4.1-6.3 *$ & $8.2-11^{*}$ & $9.3-14.5^{*}$ & $0.8-2.3$ & $0.85-2.87$ & $1.03-3.06$ \\
K (\% d.w.) & $0.5-0.8$ & $0.9-1.4$ & $1.0-1.55$ & $1.1-1.64$ & $0.8-1.2^{*}$ & $1.6-2.1 *$ & $2.6-2.8^{*}$ & $0.6-0.95$ & $0.7-1.1$ & $0.69-1.6$ \\
\hline
\end{tabular}


Benefits associated with applying biochars to soils, comparable to those of activated carbon, have been reported (Beesley et al., 2011). It was shown that increasing the pyrolysis temperature of biochars increases their degree of carbonisation, surface area, and reduces the abundance of amorphous organic matter. This also increases biochars' capability to also adsorb organic contaminants (Yu et al., 2009). Biochars obtained at high temperatures ("activated") will have the highest organic contaminant remediation potential.

Lately, biochar has been indicated as a possible substitute resource for several industrial applications in electronic and industrial applications (Huggins et al., 2014; Liu et al., 2012; Tan et al., 2015).

\section{CONCLUSIONS}

It has been herein shown that waste urban sludge can be a full component of the urban circular economy by allowing, if properly processed, recovery of energy resources at multiple levels: bio-oils (biodiesel), syngas and bio-char. These have properties that make them particularly attractive as secondary resources: bio-oils are similar in characteristics to diesel fuels, and could be used as transportation fuel or as a source of chemicals extraction; biochar has some very interesting agricultural and non-agricultural applications, and these will undoubtedly increase in the future. Biofuels' future production and use in the transport sector will be much more diversified, with biodiesel playing a greater role. The estimated growth of biodiesel production presents a fundamental issue of social sustainability due to land use for energy crops rather than food. The use of alternative renewable feedstocks such as wastewater sludge could provide support to the development of this sector, while solving a specific problem. Quantities of sewage sludge produced worldwide are increasingly growing, demanding environmentally and economically sound management in compliance with laws and regulations. Traditional disposal pathways are increasingly costly and may not be practicable in the future, due to new regulations or to diminishing public acceptance.

Use of urban waste sludge as oil-and-char feedstock has definite advantages for final residues' use and disposal; energy recovery as liquid fuel offer much more flexible (and efficient) utilization possibilities. Flexibility and multiple possibilities in the use of biochar may soon become an interesting economic issue in orienting the production of pyrolysis by-products towards economic maximization of possible returns, while significantly reducing overall GHGs emissions due to urban waste sludge disposal.

\section{REFERENCES}

AGRAFIOTI, E.; BOURAS, G.; KALDERIS, D.; DIAMADOPOULOS, E. Biochar production by sewage sludge pyrolysis. Journal of Analytical and Applied Pyrolysis, v. 101, p. 72-78, 2013. https://doi.org/10.1016/j.jaap.2013.02.010

ANTUNES, E.; SCHUMANN, J.; BRODIE, G.; JACOB, M. V.; SCHNEIDER, P. A. Biochar produced from biosolids using a single-mode microwave: Characterisation and its potential for phosphorus removal. Journal of Environmental Management, v. 196, p. 119-126, 2017. https://doi.org/10.1016/j.jenvman.2017.02.080

BEESLEY, L.; MORENO-JIMÉNEZ, E.; GOMEZ-EYLES, J. L.; HARRIS, E.; ROBINSON, B.; SIZMUR, T. A review of biochars' potential role in the remediation, revegetation and restoration of contaminated soils. Environmental Pollution, v. 159, p. 3269-3282, 2011. https://doi.org/10.1016/j.envpol.2011.07.023

BHARATHIRAJA, B.; YOGENDRAN, D.; RANJITH KUMAR, R.; CHAKRAVARTHY, M.; PALANI, S. Biofuels from sewage sludge-A review. International Journal of ChemTech Research, v .6, n. 9, p. 4417-4427, 2014. 
CAPODAGLIO, A. G. Integrated, Decentralized Wastewater Management for Resource Recovery in Rural and Peri-Urban Areas. Resources, v. 6, n. 2, p. 22, 2017. http://dx.doi.org/10.3390/resources6020022

CAPODAGLIO, A. G.; CALLEGARI, A. Feedstock and process influence on biodiesel produced from waste sewage sludge. Journal of Environmental Management, 2017 http://dx.doi.org/10.1016/j.jenvman.2017.03.089

CAPODAGLIO, A. G.; CALLEGARI, A.; CECCONET, D.; MOLOGNONI, D. Sustainability of decentralized wastewater treatment technologies. Water Practice And Technology, v. 12, n. 2, p. 463-477, 2017. http://dx.doi.org/10.2166/wpt.2017.055

CAPODAGLIO, A. G.; RANIERI, E.; TORRETTA, V. Process enhancement for maximization of methane production in co digestion biogas plants. Management of Environmental Quality: An International Journal, v. 27, n. 3, 2016a. https://doi.org/10.1108/MEQ-042015-0059

CAPODAGliO, A. G.; CALlEGARI, A.; LOPEZ, M. V. European Framework for the Diffusion of Biogas Uses: Emerging Technologies, Acceptance, Incentive Strategies, and Institutional-Regulatory Support. Sustainability, v. $8, \quad$ n. $4,2016 \mathrm{~b}$. http://dx.doi.org/10.3390/su8040298

CAPODAGliO, A. G.; CALlEGARI, A.; DONDI, D. Microwave-Induced Pyrolysis for Production of Sustainable Biodiesel from Waste Sludges. Waste Biomass Valorization, v. 7, p. 703, 2016c. https://doi.org/10.1007/s12649-016-9496-2

CHAN, K. Y.; VAN ZWIETEN, L.; MESZAROS, I.; DOWNIE, A.; JOSEPH, S. Using poultry litter biochar as soil amendments. Australian Journal of Soil Research, v. 46, p. 437444, 2008. https://doi.org/10.1071/SR08036

DEMIRBAS, A. Biomass resource facilities and biomass conversion processing for fuels and chemicals. Energy Conversion and Management, v. 42, n. 1, p. 1357-1378, 2001. https://doi.org/10.1016/S0196-8904(00)00137-0

DUFOUR, J.; IRIBARREN, D. Life cycle assessment of biodiesel production from free fatty acid-rich wastes. Renewable Energy, v. 38, p. 155-162, 2012. https://doi.org/10.1016/j.renene.2011.07.016

HOSSAIN, H. K.; STREZOV, V.; CHAN, K. Y.; NELSON, P. F. Agronomic properties of wastewater sludge biochar and bioavailability of metals in production of cherry tomato (Lycopersicon esculentum). Chemosphere, v. 78, p. 1167-1171, 2010. https://doi.org/10.1016/j.chemosphere.2010.01.009

HUGGINS, T.; WANG, H.; KEARNS, J.; JENKINS, P.; REN, Z. J. Biochar as a sustainable electrode material for electricity production in microbial fuel cells. Bioresource Technology, v. 157, p. 114-9, 2014. https://doi.org/10.1016/j.biortech.2014.01.058

KELESSIDIS, A.; STASINAKIS, A. S. Comparative study of the methods used for treatment and final disposal of sewage sludge in European countries. Waste Management, v. 32, p. 1186-1195, 2012. https://doi.org/10.1016/j.wasman.2012.01.012

LESZCZYNSKI, S. Pyrolysis of sewage sludge and municipal organic waste. Acta Metallurgica Slovaca, v. 12, p. $257-261,2006$. 
LIU, B.; WEI, Q.; ZHANG, B. et al. Life cycle GHG emissions of sewage sludge treatment and disposal options in Tai Lake watershed, China. Science of the Total Environment, v. 447, p. 361-369, 2013. https://doi.org/10.1016/j.scitotenv.2013.01.019

LIU, M-C.; KONG, L-B.; ZHANG, P.; LUO, Y-C.; KANG, L. Porous wood carbon monolith for high-performance supercapacitors. Electrochimica Acta, v. 60, p. 443-8, 2012. https://doi.org/10.1016/j.electacta.2011.11.100

LU, H.; ZHANG, W.; WANG, S.; ZHUANG, L.; YANG, Y.; QIU, R. Characterization of sewage sludge-derived biochars from different feedstocks and pyrolysis temperatures. Journal of Analytical and Applied Pyrolysis, v. 102, p. 137-143, 2013. https://doi.org/10.1016/j.jaap.2013.03.004

MACHADO, M. F. de S. A situação brasileira dos biossólidos 2001. 828f. Dissertação (Mestrado) - FEC - Universidade de Campinas, Campinas, 2001.

MASEK, O.; BUDARIN V.; GRONNOW, M.; CROMBIE, W.; BROWNSORT, P.; FITZPATRICK, E.; HURST, P. Microwave and slow pyrolysis biochar-Comparison of physical and functional properties. Journal of Analytical and Applied Pyrolysis, v. 100, p. 41-48, 2013. https://doi.org/10.1016/j.jaap.2012.11.015

MATEO-SAGASTA, J.; RASHID-SALLY, L.; THEBO, A. Global Wastewater and sludge production, treatment and use. In: DRECHSEL, P.; QADIR, M.; WICHELNS, D. (Eds.). Wastewater, Economic Asset in an Urbanizing World. Dordrecht: Springer, 2015.

MENENDEZ J. A.; INGUANZO, M.; PIS, J. J. Microwave-induced pyrolysis of sewage sludge. Water Research, v. 36, n. 13, p. 3261-64, 2002. https://doi.org/10.1016/S00431354(02)00017-9

MOTASEMI, F.; AFZAL, M. T. A review on the microwave-assisted pyrolysis technique. Renewable and Sustainable Energy Reviews, v. 28, p. 317-330, 2013. https://doi.org/10.1016/j.rser.2013.08.008

OLKIEWICZ, M.; FORTUNY, A.; STÜBER, F.; FABREGAT, A.; FONT, A.; BENGOA, C. Evaluation of different sludges from WWTP as a potential source for biodiesel production. Procedia Engineering, v. 42, p. $634-643,2012$. https://doi.org/10.1016/j.proeng.2012.07.456

PIMENTEL, D.; PATZEK, T. W. Ethanol production using corn, switchgrass, and wood; biodiesel production using soybean and sunflower. Natural Resour Research, v. 14, n. 1, p. 65, 2005. https://doi.org/10.1007/s11053-005-4679-8

POKORNA, E.; POSTELMANS, N.; JENICEK, P.; SCHREURS, S.; CARLEER, R.; YPERMAN, J. Study of bio-oils and solids from flash pyrolysis of sewage sludges. Fuel, v. 88, n. 8, p. 1344-1350, 2009. https://doi.org/10.1016/j.fuel.2009.02.020

RABONI, M.; VIOTTI, P.; CAPODAGLIO, A. G. A comprehensive analysis of the current and future role of biofuels for transport in the European union (EU). Revista Ambiente \& Agua, v. 9, n. 10, 2015. http://dx.doi.org/10.4136/ambi-agua.1492

SHACKLEY, S.; CARTER, S.; KNOWLES, T.; MIDDELINK, E.; HAEFELE, S.; SOHI, S. et al, Sustainable gasification-biochar systems? A case-study of rice-husk gasification in Cambodia, Part 1: Context, chemical properties, environmental and health and safety $\begin{array}{llllll}\text { issues. } & \text { Energy } & \text { Policy, } & \text { v. 42, }\end{array}$ https://doi.org/10.1016/j.enpol.2011.11.026 
SHIZAS, I.; BAGLEY, D. M. Experimental Determination of Energy Content of Unknown Organics in Municipal Wastewater Streams. Journal of Energy Engineering, v. 130, n. 2, 2004. https://doi.org/10.1061/(ASCE)0733-9402(2004)130:2(45)

TAN, X.; LIU, Y.; ZENG, G.; WANG, X.; HUA, X.; GU, Y.; YANG, Z. Application of biochar for the removal of pollutants from aqueous solutions. Chemosphere, v. 125, p. 70-85, 2015. https://doi.org/10.1016/j.chemosphere.2014.12.058

TORRES, E. A.; CERQUEIRA, G. S.; FERRER, T. M.; QUINTELLA, C. M.; RABONI, M.; TORRETTA, V. et al. Recovery of different waste vegetable oils for biodiesel production: A pilot experience in Bahia State, Brazil, Waste Management, v. 33, p. 2670-2674, 2013. https://doi.org/10.1016/j.wasman.2013.07.030

VESILIND, P. A.; RAMSEY, T. B. Effect of drying temperature on the fuel value of wastewater sludge. Waste Management \& Research, v. 14, n. 2, p. 189-196, 1996. https://doi.org/10.1177\%2F0734242X9601400208

YU, X. Y.; YING, G. G.; KOOKANA, R. S. Reduced plant uptake of pesticides with biochar $\begin{array}{lllllll}\text { additions to soil. Chemosphere, v. 76, p. 665-671, } 2009 . & \end{array}$ https://doi.org/10.1016/j.chemosphere.2009.04.001

ZANONI, A. E.; MUELLER, D. L. Calorific value of wastewater plant sludges. Journal of the Environmental Engineering Division (ASCE), v. 108, n. 1, p. 187-195, 1982.

ZHANG, X.; YAN, S.; TYAGI, R. G.; SURAMPALLI, Y. R. Energy balance and greenhouse gas emissions of biodiesel production from oil derived from wastewater and wastewater sludge. Renewable Energy, v. 55, p. 392-403, 2013. https://doi.org/10.1016/j.renene.2012.12.046

ZIELINSKA, A.; OLESZCZUK, P.; CHARMAS, B.; SKUBISZEWSKA-ZIEBA, J.; PASIECZNA-PATKOWSKA, Z. Effect of sewage sludge properties on the biochar characteristic. Journal of Analytical and Applied Pyrolysis, v. 112, p. 201-213, 2015. https://doi.org/10.1016/j.jaap.2015.01.025 